\title{
Prevalence and factors associated with hypertriglyceridemic waist in the elderly: a population-based study
}

\author{
Prevalência e fatores associados à cintura hipertrigliceridêmica \\ em idosos: um estudo de base populacional
}

Luara Costa Fagundes ${ }^{1}$
Marcos Henrique Fernandes ${ }^{1}$
Thais Alves Brito $^{1}$
Raildo da Silva Coqueiro $^{1}$
José Ailton Oliveira Carneiro $^{1}$
${ }^{1}$ Departamento de Saúde, Universidade Estadual do Sudoeste da Bahia. R. José Moreira Sobrinho $\mathrm{s} / \mathrm{n}^{\circ}$, Jequiezinho. 45206-190 Jequié BA Brasil.

hitoef@yahoo.com.br

\begin{abstract}
To identify the prevalence and factors associated with hypertriglyceridemic waist $(H W)$ in community-dwelling elderly people in northeast Brazil. Population-based cross-sectional study. Some 316 elderly ( $\geq 60$ years) people of both sexes participated in this study. Data were collected using a questionnaire, based on that used in the Health, Welfare and Aging Study (SABE), in addition to blood tests, blood pressure measurements and anthropometric measurements. The hypertriglyceridemic waist condition was diagnosed using high values of triglycerides $(\geq 150$ $\mathrm{mg} / \mathrm{dl}$ ) and waist circumference increased $\geq 88$ and $\geq 102 \mathrm{~cm}$ for women and men, respectively. Logistic regression analysis was used to compare the hypertriglyceridemic waist and associated factors, significance level of 5\%. The prevalence of hypertriglyceridemic waist $(\mathrm{HW})$ was $27.1 \%$. The logistic regression model (OR) adjusted showed the condition of $H W$ associated to the feminine sex (OR 4.19), to the insufficiently active elderly (OR 2.41) and with overweight (OR 4.06). A high prevalence (27.1\%) of hypertriglyceridemic waist was observed, indicating the female sex, physical inactivity and overweight as key factors associated with hypertriglyceridemic waist in community-dwelling elderly people.
\end{abstract}

Key words Elderly, Obesity, Hypertriglyceridemic waist
Resumo Identificar a prevalência e os fatores associados à cintura hipertrigliceridêmica em idosos residentes em uma comunidade no nordeste do Brasil. Estudo populacional com delineamento transversal. Participaram do estudo 316 idosos com idade $\geq 60$ anos, de ambos os sexos. Os dados foram coletados por meio de um formulário próprio, baseado no questionário usado na Pesquisa Saúde, Bem-Estar e Envelhecimento, além dos exames sanguineos, aferição da pressão arterial e medidas antropométricas. A cintura hipertrigliceridêmica $(\mathrm{CH})$ foi diagnosticada quando os níveis de triglicerídeos apresentaram valores $(\geq 150 \mathrm{mg}$ ) dl) e a circunferência da cintura $\geq 88 \mathrm{~cm}$ para as mulheres e 102 para os homens. Para identificar os fatores associados a $\mathrm{CH}$ foi utilizado a análise de regressão logística, com nível de significância 5\%. A prevalência de cintura hipertrigliceridêmica foi $27,1 \%$. O modelo de regressão logística (OR) ajustado mostrou a condição de CH associada ao sexo feminino (OR 4.19), aos idosos insuficientemente ativos (OR 2.41) e com sobrepeso (OR 4.06). Foi observada uma alta prevalência de cintura hipertrigliceridêmica em idosos residentes em comunidade, apontando o sexo feminino, a inatividade física e o sobrepeso/obesidade como fatores associados.

Palavras-chave Idoso, Obesidade, Cintura hipertrigliceridêmica 


\section{Introduction}

The hypertriglyceridemic waist (HW) condition is a phenotype characterized by the simultaneous association of increased waist circumference (abdominal obesity) and hypertriglyceridemia ${ }^{1}$. The combination of these two factors is associated with higher risks of cardiometabolic disorders ${ }^{2}$. In addition, individuals with 40 years or more with hypertriglyceridemic waist have a higher risk of developing chronic kidney disease ${ }^{3}$.

The evaluation of the hypertriglyceridemic waist phenotype can be used in clinical practice as a screening approach to identify individuals with an increased probability of having the atherogenic metabolic triad: fasting hyperinsulinemia, hyperapolipoprotein $\mathrm{B}$ and a high concentration of small LDL (Low density lipoprotein cholesterol) particles ${ }^{4}$. Moreover, this phenotype can reliably identify patients with an increased cardiometabolic risk profile ${ }^{5}$, as well as being low $\operatorname{cost}^{2}$.

In a study by Cabral et al. ${ }^{6}$ with hypertensive women, an association was observed between hypertriglyceridemic waist and smoking, overweight, hypercholesterolemia, diabetes mellitus and decreased HDL (high-density lipoprotein) cholesterol. Moreover, the hypertriglyceridemic waist is also related with physical inactivity, skin color, family income, intake of fats and high BMI (body mass index) ${ }^{7}$.

However, until now, no population-based studies have examined the relationship between hypertriglyceridemic waist and associated factors in the elderly. Accelerated aging of the population is associated with increased prevalence of non-transmissible chronic diseases, such as cardiovascular disease ${ }^{8}$. Cardiovascular mortality in the elderly is associated with reduced HDL and high triglyceride levels. Moreover, dyslipidemia and obesity are also frequent in this age group ${ }^{9}$.

Considering the absence of population-based research regarding hypertriglyceridemic waist in the elderly, this study aimed to identify the prevalence and factors associated with hypertriglyceridemic waist in elderly residents in a community in the northeast of Brazil.

\section{Method}

This is a study based on data from an epidemiologic cross-sectional, population-based household survey called "Nutritional status, risk behaviors, and health conditions of the older adults of Lafaiete Coutinho-Bahia, Brazil". This study was conducted according to the Helsinki Declaration, and the local Ethics Committee approved the procedures involved. Prior to the data collection, volunteers signed an acknowledged consent form.

The city studied, located in northeastern Brazil, had 4162 inhabitants during the period of data collection, all registered with the Family Health Strategy (FHS). The city has one of the worst human development indexes (HDIs) in Brazil, occupying the 4487th position on the longevity category (longevity-HDIM $=0.635)^{10}$.

A complete census was conducted in Lafaiete Coutinho (January 2011) for the identification of older adults ( $\geq 60$ years). The location of the residences was conducted using information from the Family Health Strategy, a program of primary health care that covers the entire county. All older adults residing in urban areas $(n=355)$ were contacted. Of the 355 individuals who comprised the study population, 316 (89\%) participated in the study: 17 refusals were recorded $(4.8 \%)$ and $22(6.2 \%)$ individuals were not located after three visits on alternate days, and were considered sample loss.

Data collection occurred in two stages. The first consisted of an interview, conducted by only the individual interviewer, including personal information, health status, medication use and lifestyle. The second stage was conducted in two units of the FHP of the city and included blood pressure measurement and anthropometry; this step was scheduled with an interval of 1-3 days after the home interview.

To collect the data was used a specific form, based on the questionnaire used in the Search Health, Welfare and Aging (SABE) project, realized in seven countries in Latin America and the Caribbean, with the exception of the physical activity questionnaire which, in the present study, used the long version ${ }^{11}$. Details about the data collection, have been previously published ${ }^{12}$.

\section{Hypertriglyceridemic waist (Dependent variable)}

The waist circumference was measured at the level of the umbilical scar using an inelastic anthropometric tape (ABN ${ }^{\mathrm{TM}}$, Brazil). The cutoff points used to define abdominal obesity were $>$ $88 \mathrm{~cm}$ for women and $>102 \mathrm{~cm}$ for $\mathrm{men}^{13}$. To measure 12 hours fasting triglycerides, the Accutrend ${ }^{\circledR}$ Plus system was used (Roche Diagnostics, Germany), as previously validated ${ }^{14}$. Capillary blood samples were collected through transcu- 
taneous puncture on the medial side of the tip of the middle finger using a disposable hypodermic lancet. Prior to puncture, 70\% alcohol was applied to promote antisepsis. Hypertriglyceridemia (triglycerides $\geq 150 \mathrm{mg} / \mathrm{dl}$ ) was defined according to the current Brazilian guidelines ${ }^{15}$. The hypertriglyceridemic waist phenotype was defined as the presence of the abdominal obesity plus hypertriglyceridemia.

\section{Independent variables}

Sociodemographic: Sex (male and female); Age group (60-69, 70-79, $\geq 80$ years); Marital status (single and live with partner) and Literacy (yes/no).

Lifestyle: Alcoholic beverages intake ( $<1$ day/ week and $\geq 1$ day/week); Smoking (smoker, former-smoker and never smoked); Intake of fruit and vegetables ( $>4$ times a week and $<4$ times a week); Physical activity level was evaluated using the international physical activity questionnaire (IPAQ), long version ${ }^{11}$. The elderly who spent less than 150 minutes per week in moderate or vigorous physical activities were considered insufficiently active; and those who spent more than 150 minutes per week in physical activities were considered active.

Health conditions: High blood pressure (yes/ no). The elderly that presented with systolic pressure $\geq 140 \mathrm{mmHg}$ and/or diastolic pressure $\geq 90 \mathrm{mmHg}$ and/or use of medication to control blood pressure were considered as having high blood pressure ${ }^{16}$; Fasting glycemia $(<100 \mathrm{mg} / \mathrm{dL}$ $\mathrm{e} \geq 100 \mathrm{mg} / \mathrm{dL})^{17}$, Total cholesterol $(<200 \mathrm{mg} /$ $\mathrm{dL}$ and $\geq 200 \mathrm{mg} / \mathrm{dL})^{15}$, Body mass index (BMI = $\left.\mathrm{kg} / \mathrm{m}^{2}\right)^{18}: \mathrm{BMI}<22 \mathrm{Kg} / \mathrm{m}^{2}=$ underweight, $22 \leq$ $\mathrm{BMI} \leq 27 \mathrm{Kg} / \mathrm{m}^{2}=$ normal and $\mathrm{BMI}>27 \mathrm{Kg} / \mathrm{m}^{2}$ $=$ overweight.

The instruments and procedures used to evaluate the blood pressure, body weight and height have been reported previously ${ }^{12}$. The Accutrend ${ }^{\circledast}$ Plus system was utilized to determine glycemia and total cholesterol, following the same procedures described previously to determine the triglycerides.

\section{Statistical analysis}

The association between hypertriglyceridemic waist and the independent variables was verified by means of the logistic regression. In crude analyses, the prevalence of hypertriglyceridemic waist was calculated for each category of the independent variables, and the level of sig- nificance was tested by means of the Wald test for heterogeneity. The variables that presented statistical significance of at least 20\% ( $\leq \leq 0.20)$ in the crude analyses were included in the adjusted analysis, following the order of a hierarchical model for determination of the outcomes (Figure 1). In accordance with the established model, the variables of the higher levels (distal) interact and determine the variables of the lower levels (proximal). The effect of each explanatory variable on the outcome was controlled for the variables of the same level and of higher levels in the model. The significance level adopted in the study was $5 \%$. The data were analyzed using the statistical program SPSS ${ }^{\varpi}$ version 21.0.

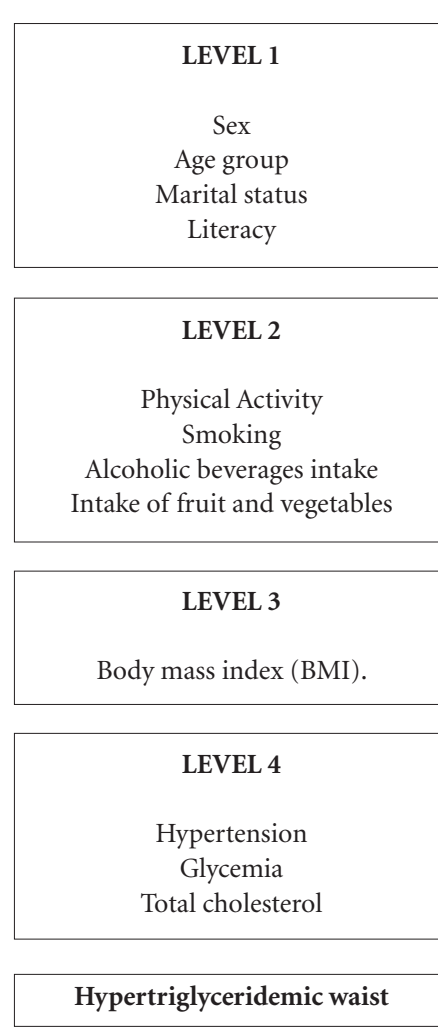

Figure 1. Conceptual model of determination of the outcome used in the multiple analysis. Lafaiete Coutinho, Brazil, 2011. 


\section{Results}

The participants in the study were 173 women (54.7\%) and 143 men (45.3\%). Their ages varied between 60 to 105 years (mean $74.2 \pm 9.8$ years). The mean age of the women was $74.9 \pm$ 10 years $(60-103$ years $)$ and of the men $73.4 \pm$ 9.4 years ( $60-105$ years). The prevalence of hypertriglyceridemic waist phenotype was $27.1 \%$ (Response rate $=96.4 \%)$. The other characteristics of the study population are presented in the Table 1.
The Table 2 shows the prevalence of hypertriglyceridemic waist, in accordance with the explanatory variables of the study. The hypertriglyceridemic waist condition was significantly more frequent in women, and individuals who were insufficiently active, having hypertension, hyperglycemia and those with hypercholesterolemia. However, the hypertriglyceridemic waist was less frequent among the individuals with a lower intake of fruit and vegetables and underweight. The results of the crude analysis showed that, except for the age group and alcoholic in-

Table 1. Characteristics of the study population. Lafaiete Coutinho, Brazil, 2011.

\begin{tabular}{|c|c|c|c|}
\hline Variables & \% response & $\mathrm{N}$ & $\%$ \\
\hline Age group (years) & 99.7 & & \\
\hline $60-69$ & & 115 & 36.5 \\
\hline $70-79$ & & 106 & 33.7 \\
\hline$\geq 80$ & & 94 & 29.8 \\
\hline Body mass index & 95.3 & & \\
\hline Underweight & & 87 & 28.9 \\
\hline Normal & & 128 & 42.5 \\
\hline Overweight & & 86 & 28.6 \\
\hline Marital status & 100.0 & & \\
\hline Single & & 52 & 16.5 \\
\hline Living with partner & & 264 & 83.5 \\
\hline Literacy & 100.0 & & \\
\hline Yes & & 105 & 33.2 \\
\hline No & & 211 & 66.8 \\
\hline Physical activity & 98.1 & & \\
\hline Insufficiently active & & 148 & 47.7 \\
\hline Active & & 162 & 52.3 \\
\hline Intake of fruit and vegetables & 98.7 & & \\
\hline$\geq 4$ times a week & & 223 & 71.5 \\
\hline$<4$ times a week & & 89 & 28.5 \\
\hline Smoking & 99.7 & & \\
\hline Smoker & & 35 & 11.1 \\
\hline Former-smoker & & 147 & 46.7 \\
\hline Never smoked & & 133 & 42.2 \\
\hline Alcoholic beverages intake & 99.7 & & \\
\hline$<1$ day/week & & 55 & 17.5 \\
\hline$\geq 1$ day/week & & 260 & 82.5 \\
\hline Hypertension & 96.8 & & \\
\hline Yes & & 256 & 83.7 \\
\hline No & & 50 & 16.3 \\
\hline Glycemia (mg/dL) & 97.8 & & \\
\hline$<100$ & & 251 & 81.2 \\
\hline$\geq 100$ & & 58 & 18.8 \\
\hline Total cholesterol (mg/dL) & 97.2 & & \\
\hline$<200$ & & 146 & 47.6 \\
\hline$\geq 200$ & & 161 & 52.4 \\
\hline
\end{tabular}


Table 2. Prevalence of hypertriglyceridemic waist its relationship with the explanatory variables of the study. Lafaiete Coutinho, Brazil, 2011.

\begin{tabular}{|c|c|c|c|c|c|}
\hline Level & Variables & $\%$ & OR crude & IC95\% & p-value \\
\hline \multirow{12}{*}{1} & Sex & & & & $<0.001$ \\
\hline & Female & 38.3 & 3.85 & $2.16-6.87$ & \\
\hline & Male & 13.9 & 1 & & \\
\hline & Age group (years) & & & & 0.218 \\
\hline & $60-69$ & 21.6 & 1 & & \\
\hline & $70-79$ & 32.0 & 1.71 & $0.92-3.15$ & \\
\hline & $\geq 80$ & 28.2 & 1.42 & $0.74-2.74$ & \\
\hline & Marital status & & & & 0.101 \\
\hline & Single & 18.0 & 0.54 & $0.24-1.17$ & \\
\hline & Living with partner & 28.9 & 1 & & \\
\hline & Literacy & & & & 0.179 \\
\hline & Yes & 32.0 & 1 & & \\
\hline \multirow{14}{*}{2} & No & 24.6 & 0.69 & $0.41-1.18$ & \\
\hline & Physical activity & & & & 0.024 \\
\hline & Insufficiently active & 33.8 & 1.81 & $1.08-3.03$ & \\
\hline & Active & 22.0 & 1 & & \\
\hline & Smoking & & & & $<0.001$ \\
\hline & Smoker & 3.0 & 0.05 & $0.01-0.41$ & \\
\hline & Former-smoker & 24.5 & 0.55 & $0.32-0.94$ & \\
\hline & Never smoked & 36.9 & 1 & & \\
\hline & Alcoholic beverages intake & & & & 0.313 \\
\hline & $<1$ day/week & 21.8 & 1 & & \\
\hline & $\geq 1$ day/week & 28.4 & 1.42 & $0.71-2.85$ & \\
\hline & Intake of fruit and vegetables & & & & 0.015 \\
\hline & $\geq 4$ times a week & 30.8 & 1 & & \\
\hline & $<4$ times a week & 17.4 & 0.47 & $0.25-0.90$ & \\
\hline \multirow{4}{*}{3} & Body mass index & & & & $<0.001$ \\
\hline & Underweight & 2.3 & 0.08 & $0.02-0.35$ & \\
\hline & Normal & 22.8 & 1 & & \\
\hline & Overweight & 58.1 & 4.7 & $2.59-8.52$ & \\
\hline \multirow{9}{*}{4} & Hypertension & & & & $<0.001$ \\
\hline & Yes & 30,4 & 4.91 & $1.70-14.13$ & \\
\hline & No & 8.2 & 1 & & \\
\hline & Glycemia (mg/dL) & & & & 0.006 \\
\hline & $\geq 100$ & 42.6 & 2.39 & $1.29-4.42$ & \\
\hline & $<100$ & 23.7 & 1 & & \\
\hline & Total Cholesterol (mg/dL) & & & & 0.011 \\
\hline & $\geq 200$ & 33.1 & 1.96 & $1.60-3.33$ & \\
\hline & $<200$ & 20.1 & 1 & & \\
\hline
\end{tabular}

take, the other explanatory variables reached statistical significance $(\mathrm{p} \leq 0.20)$ sufficient to be included in the multiple model.

After of the inter- and intra-level adjustments in accordance with the hierarchic model, the variables glycemia and hypercholesterolemia were not included in the final model, as they did not meet the significance criterion $(\mathrm{p} \leq 0.20)$.

The hypertriglyceridemic waist was positively associated with the female sex, and individuals who were insufficiently active and overweight. There was an inverse association between hyper- 
triglyceridemic waist and literacy, smoking and being underweight. Although they have been retained in the final model for adjustment purposes, the variables marital status, intake of fruit and vegetables and hypertension were not associated with hypertriglyceridemic waist (Table 3).

\section{Discussion}

This study determined the prevalence of hypertriglyceridemic waist (HW) and associated factors in community-dwelling elderly people. The main findings showed a prevalence of $27.1 \%$ of hypertriglyceridemic waist in the elderly, and this is strongly associated with the feminine sex, physical inactivity and overweight/obesity. According to our knowledge, this was the first household-based population study to investigate the prevalence of HW and associated factors in older adults of both sexes.
In the present study, the prevalence of HW approached that observed by Cabral et al. ${ }^{6}(33 \%)$ in hypertensive women with a mean age of 60.9 years. International studies with younger age ranges showed a prevalence of HW that ranged from 10.8 to $35.2 \%^{19-22}$. This variation may be due to the use of different cutoff points for waist circumference and serum triglyceride levels, in addition to the different age ranges.

In the adjusted analysis of the present study, women were approximately $\sim 4$ times, the insufficiently active elderly $\sim 2.5$ times and the elderly with overweight/obesity problems $\sim 4.1$ times more likely to develop HW.

To our knowledge the association between HW and elderly females has not been reported previously. However, studies with middle-aged individuals, also found an association between females and $\mathrm{HW}^{19,22}$. According Bentley-Lewis et al. ${ }^{23}$, noted pregnancy, gestational diabetes mellitus, pre-eclampsia, hormonal contraceptives,

Table 3. Model of hierarchical regression of the relationship between hypertriglyceridemic waist and the explanatory variables of the study. Lafaiete Coutinho, Brazil, 2011.

\begin{tabular}{|c|c|c|c|}
\hline Variables & OR adjusted & IC95\% & p-value \\
\hline \multicolumn{4}{|l|}{ Sex } \\
\hline Female & 4.19 & $2.31-7.59$ & $<0.001$ \\
\hline Male & 1 & & \\
\hline \multicolumn{4}{|l|}{ Marital status } \\
\hline Single & 0.55 & $0.25-1.23$ & 0.148 \\
\hline Living with partner & 1 & & \\
\hline \multicolumn{4}{|l|}{ Literacy } \\
\hline Yes & 1 & & \\
\hline No & 0.54 & $0.30-0.95$ & 0.033 \\
\hline \multicolumn{4}{|l|}{ Physical activity } \\
\hline Insufficiently active & 2.41 & $1.34-4.34$ & 0.003 \\
\hline Active & 1 & & \\
\hline \multicolumn{4}{|l|}{ Smoking } \\
\hline Smoker & 0.10 & $0.01-0.79$ & 0.029 \\
\hline Former-smoker & 0.78 & $0.43-1.45$ & 0.435 \\
\hline Never smoked & 1 & & \\
\hline \multicolumn{4}{|l|}{ Intake of fruit and vegetables } \\
\hline$\geq 4$ times a week & 1 & & \\
\hline$<4$ times a week & 0.63 & $0.2-1.27$ & 0.198 \\
\hline \multicolumn{4}{|l|}{ Body mass index. } \\
\hline Underweight & 0.07 & $0.02-0.32$ & 0.001 \\
\hline Normal & 1 & & \\
\hline Overweight & 4.06 & $2.08-7.93$ & $<0.001$ \\
\hline \multicolumn{4}{|l|}{ Hypertension } \\
\hline Yes & 2.82 & $0.82-9.71$ & 0.101 \\
\hline No & 1 & & \\
\hline
\end{tabular}


menopause and polycystic ovary syndrome are several factors unique to women that can have an impact on the prevalence and characteristics of metabolic syndrome in women. In addition, Cornier et al. ${ }^{24}$ relate that a higher prevalence of metabolic syndrome among women may be due to different socioeconomic status, work-related activities and cultural perception of body image. Hypertriglyceridemic waist was proposed as an alternative and cost-effective tool to assess cardiometabolic risk that was also associated with metabolic syndrome.

In this study, excess weight in the elderly proved to be a determining factor for development of the HW. The association between HW and excess weight in the elderly has also not been reported previously. Nevertheless, several studies with different age ranges have also observed an association between excess weight and hypertriglyceridemic waist ${ }^{2,6,7,25}$. The elderly with HW presented global obesity as assessed by BMI. According Oliveira et $\mathrm{al}^{26}$, the increase of the global obesity is associated with increased visceral fat; this may be explained by the strong correlation between BMI and WC, which is considered a simple measure of abdominal obesity and may better reflect the accumulation of intra-abdominal fat ${ }^{27}$. In the elderly, excess body fat can be intensified due to changes in body composition during aging, where there is often a loss of muscle mass and an increase of $\mathrm{fat}^{28}$.

According to Fakhouri et al. ${ }^{29}$, more than one-third of older adults aged 65 and over were classed as obese in 2007-2010 in the United States. Overweight and obesity lead to adverse metabolic effects on blood pressure, cholesterol, triglycerides and insulin resistance, increased risk for chronic diseases, including type 2 diabetes, cardiovascular disease, hypertension and stroke, and certain forms of cancer $^{13}$.

In this study, another important factor that was clearly associated with HW was the low level of physical activity in older adults. To our knowledge the association between HW and physical inactivity specifically in the elderly also has not been reported previously. However, in the study of Irving et al. ${ }^{30}$ with adults, the authors reported that the presence of hypertriglyceridemic waist can be associated with physical inactivity. However, studies have shown physical inactivity as a strong risk factor for cardiovascular disease ${ }^{31}$ and metabolic syndrome ${ }^{32}$ in the elderly.

Therefore, interventions focused on lifestyle such as practice of physical activity associated with healthy eating, can be powerful tools for prevention or reversion of the HW.

In this study, the HW was inversely associated with literacy, smoking and underweight. To our knowledge this has not been reported previously in the elderly. However, underweight is clearly a factor against HW, as studies indicate that underweight elderly people have a lower waist circumference and lower risk for cardiovascular disease $^{33}$ and metabolic syndrome ${ }^{34}$. However, the literacy and smoking factors need to be analyzed more cautiously, where studies have noted these variables as risk factors for cardiovascular disease $^{35,36}$, and can be best studied with longitudinal follow-up research.

The limitations of this study are inherent to its cross-sectional design, which does not allow a causal relationship between hypertriglyceridemic waist and associated factors in the elderly. Moreover, the absence of studies on HW and associated factors with a specific elderly population has limited discussion. However, the hypertriglyceridemic waist phenotype represents a simple and inexpensive tool to screen elderly people with cardiometabolic risk, which can be used in clinical practice and by health professionals, especially in primary care.

\section{Conclusion}

Based on the findings of this study, it is possible conclude that hypertriglyceridemic waist is a disorder with a high prevalence in the elderly, being associated with the female sex, physical inactivity and overweight.

However, becomes important the implementation of public policy geared towards women, as well as actions that promote physical activity and $\mathrm{BMI}$ reduction. 


\section{Collaborations}

LC Fagundes, MH Fernandes and TA Brito participated in the design of the study and helped to draft the manuscript. RS Coqueiro and JAO Carneiro participated in the design of the study, performed the statistical analysis and helped to draft the manuscript. All authors read and approved the final manuscript to be published.

\section{Acknowledgements}

The research was partly funded by the UESB. The authors thank the Municipal Secretariat of Health of Lafaiete Coutinho-BA and the elderly people who participated in the study.

\section{References}

1. Lemieux I, Pascot A, Couillard C, Lamarche B, Tchernof A, Alméras N, Després JP. Hypertriglyceridemic waist: A marker of the atherogenic metabolic triad (hyperinsulinemia; hyperapolipoprotein $\mathrm{B}$; small, dense LDL) in men? Circulation 2000; 102(2):179-184.

2. Arsenault BJ, Lemieux I, Despres JP, Wareham NJ, Kastelein JJ, Khaw KT, Boekholdt SM. The hypertriglyceridemic-waist phenotype and the risk of coronary artery disease: results from the EPIC-Norfolk prospective population study. CMAJ 2010; 182(13):1427-1432.

3. Li Y, Zhou C, Shao X, Liu X, Guo J, Zhang Y, Zou H. Hypertriglyceridemic waist phenotype and chronic kidney disease in a chinese population aged 40 years and older. PLoS One 2014; 9:e92322.

4. Lemieux I, Poirier P, Bergeron J, Alméras N, Lamarche B, Cantin B, Després JP. Hypertriglyceridemic waist: a useful screening phenotype in preventive cardiology? Can J Cardiol 2007; 23(Supl. B):23B-31B.

5. Blackburn P, Lemieux I, Almeras N, Bergeron J, Côté M, Tremblay A, Lamarche B, Després JP. The hypertriglyceridemic waist phenotype versus the National Cholesterol Education Program-Adult Treatment Panel III and International Diabetes Federation clinical criteria to identify high-risk men with an altered cardiometabolic risk profile. Metabolism 2009; 58(8):1123-1130.

6. Cabral NAL, Ribeiro VS, França AKTC, Salgado JVL, Santos AM, Filho NS, Silva AAM. Cintura hipertrigliceridêmica e risco cardiometabólico em mulheres hipertensas. Rev. Assoc Med Bras 2012; 58(5):568-573.

7. Haack RL, Horta BL, Gigante DP, Barros FC, Oliveira I, Silveira VM. The hypertriglyceridemic waist phenotype in young adults from the Southern Region of Brazil. Cad Saude Publica 2013; 29(5):999-1007.

8. Gottlieb MGV, Schwanke CHA, Gomes I, Cruz IBM Longevity and aging in Rio Grande do Sul state: a hystorical, ethnic and morbi-mortality profile of elderly people. Rev Bras Geriatr Gerontol 2011; 14(2):365-380.

9. Nagatsuyu DT, Moriguti EKU, Pfrimer K, Formighieri PF, Lima NKC, Ferriolli E, Moriguti JC. O impacto da obesidade abdominal sobre os níveis plasmáticos de lípideos nos idosos. Medicina (Ribeirão Preto) 2009; 42(2):141-147.

10. Programa das Nações Unidas para o Desenvolvimento (PNUD). Atlas de desenvolvimento humano no Brasil. Brasília: PNUD; 2012.

11. Craig CL, Marshall AL, Sjöström M, Bauman AE, Booth ML, Ainsworth BE, Oja P. International physical activity questionnaire: 12 -country reliability and validity. Med Sci Sports Exerc 2003; 35(8):1381-1395.

12. Leal Neto JS, Coqueiro RS, Freitas RS, Fernandes MH, Oliveira DS, Barbosa AR. Anthropometric indicators of obesity as screening tools for high blood pressure in the elderly. Int J Nurs Pract 2013; 19(4):360-367.

13. World Health Organization (WHO). Obesity: preventing and managing the global epidemic. Report of a WHO consultation. Washington: WHO; 2000. (World Health Organization Technical Report Series 894).

14. Coqueiro RS, Santos MC, Leal Neto JS, Queiroz BM, Brügger NA, Barbosa AR. Validity of a glucose, total cholesterol and triglycerides portable multi analyzer in adults. Biol Res Nurs 2013; 16(3):288-294. 
15. Xavier HT, Izar MC, Faria Neto JR, Assad MH, Rocha VZ, Sposito AC, Ramires JAF. V Diretriz Brasileira de Dislipidemias e Prevenção da Aterosclerose. Arq Bras Cardiol 2013; 101(4 Supl. 1):1-20.

16. Sociedade Brasileira de Cardiologia, Sociedade Brasileira de Hipertensão, Sociedade Brasileira de Nefrologia. VI Diretrizes Brasileiras de Hipertensão. Arq Bras Cardiol 2010; 95(1 Supl. 1):1-51.

17. Sociedade Brasileira de Diabetes. Diretrizes da Sociedade Brasileira de Diabetes: 2013-2014. São Paulo: AC Farmacêutica; 2014.

18. American Academy of Family Physicians, American Dietetic Association, National Council on the Aging. Nutrition screening e intervention resources for healthcare professionals working with older adults. Nutrition Screening Initiative. Washington: American Dietetic Association; 2002.

19. Zainuddin LR, Isa N, Muda WM, Mohamed HJ. The prevalence of metabolic syndrome according to various definitions and hypertriglyceridemic-waist in malaysian adults. Int J Prev Med 2011; 2(4):229-237.

20. Egeland GM, Cao Z, Young TK. Hypertriglyceridemic-waist phenotype and glucose intolerance among Canadian Inuit: the International Polar Year Inuit Health Survey for Adults 2007-2008. CMAJ 201; 183(9):553558.

21. Gomez-Huelgas R, Bernal-Lopez MR, Villalobos A, Mancera-Romero J. Baca-Osorio AJ, Jansen, Serrano-Ríos M. Hypertriglyceridemic waist: an alternative to the metabolic syndrome? Results of the IMAP Study (multidisciplinary intervention in primary care). Int $\mathrm{J}$ Obes (Lond) 2011; 35(2):292-299.

22. Amini M, Esmaillzadeh A, Sadeghi M, Mehvarifar N, Amini M, Zare M. The association of hypertriglyceridemic waist phenotype with type 2 diabetes mellitus among individuals with first relative history of diabetes. J Res Med Sci 2011; 16(2):156-164.

23. Bentley-Lewis R, Koruda K, Seely EW. The metabolic syndrome in women. Nat Clin Pract Endocrinol Metab 2007; 3(10):696-704.

24. Cornier MA, Dabelea D, Hernandez TL, Lindstrom RC, Steig AJ, Stob NR, Eckel RH. The metabolic syndrome. Endocr Rev 2008; 29(7):777-822.

25. Gasevic D, Carlsson AC, Lesser IA, Mancini GJ, Lear SA. The association between "hypertriglyceridemic waist" and sub-clinical atherosclerosis in a multiethnic population: a cross-sectional study. Lipids Health Dis 2014; 13:38

26. Oliveira MAM, Fagundes RLM, Moreira EAM, Trindade EBSM, Carvalho T. Relação de indicadores antropométricos com fatores de risco para doença cardiovascular. Arq Bras Cardiol 2010; 94(4):478-485.

27. Feng RN, Zhao C, Wang C, Niu YC, Li K, Guo FC, Li ST, Sun CH, Li Y. BMI is strongly associated with hypertension, and waist circumference is strongly associated with type 2 diabetes and dyslipidemia, in northern Chinese adults. J Epidemiol 2012; 22(4):317-323.

28. Barbosa AR, Santarém JM, Jacob Filho W, Meirelles ES, Marucci JM. Comparison of Body fat using anthropometry, bioeletrical imedance and DEXA in elderly women. Arch Latinoam Nutr 2001; 51(1):49-56.
29. Fakhouri THI, Ogden CL, Carroll MD, Kit BK, Flegal KM. Prevalence of Obesity Among Older Adults in the United States, 2007-2010. NCHS Data Brief 2012; (106):1-8.

30. Irving BA, Davis CK, Brock DW, Weltman JY, Swift D, Barrett EJ, Gaesser GA, Weltman A. The metabolic syndrome, hypertriglyceridemic waist, and cardiometabolic risk factor profile in obese women. Obe Metab 2007; 3(2):50-57.

31. Pereira JC, Barreto SM, Passos VMA. The Profile of Cardiovascular Health of Elderly Brazilian People Needs to Improve: a Population-Based Study. Arq Bras Cardiol 2008; 91(1):1-10.

32. Bankoski A, Harris TB, McClain JJ, Brychta RJ, Caserotti P, Chen KY, Koster A. Sedentary activity associated with metabolic syndrome independent of physical activity. Diabetes care 2011; 34(2):497-503.

33. Galal W, Van GY, Hoeks SE, Sin DD, Winkel TA, Bax JJ, Poldermans D. The obesity paradox in patients with peripheral arterial disease: the influence of chronic obstructive pulmonary disease. Chest 2009; 134(5):925930.

34. Zhao Y, Yan H, Yang R, Li Q, Dang S, Wang Y. Prevalence and Determinants of Metabolic Syndrome among Adults in a Rural Area of Northwest China. PLoS ONE 2014; 9:e91578.

35. Lidfeldt J, Nyberg P, Nerbrand C, Samsioe G, Scherstén B, Agardh CD. Sociodemographic and psychosocial factors are associated with features of the metabolic syndrome. The Women's Health in the Lund Área (Whila) Study. Diabetes Obes Metab 2003; 5(2):106112.

36. Leitão MPC, Martins IS. Prevalence and factors associated with metabolic syndrome in users of primary healthcare units in São Paulo - SP, Brazil. Rev Assoc Med Bras 2012; 58(1):60-69.

Artigo apresentado em 03/02/2016

Aprovado em 12/05/2016

Versão final apresentada em 14/05/2016 
